\title{
RESEARCH
}

Open Access

\section{Efficacy of mesenchymal stem cell therapy for sepsis: a meta-analysis of preclinical studies}

Xue-Yi Sun $^{\dagger}{ }^{\mathbb{D}}$, Xian-Fei Ding ${ }^{\dagger}$, Huo-Yan Liang, Xiao-Juan Zhang, Shao-Hua Liu, Bing-Han, Xiao-Guang Duan and Tong-Wen Sun ${ }^{*}$

\begin{abstract}
Background: Multiple studies have reported that mesenchymal stem cell (MSC) therapy has beneficial effects in experimental models of sepsis. However, this finding remains inconclusive. This study was performed to systematically determine the connection between MSC therapy and mortality in sepsis animal models by pooling and analyzing data from newly published studies.

Methods: A detailed search of related studies from 2009 to 2019 was conducted in four databases, including MEDLINE, EMBASE, Cochrane Library, and Web of Science. After browsing and filtering out articles that met the inclusion criteria for statistical analysis, the inverse variance method of the fixed effects model was used to calculate the pooled odds ratios (ORs) and their 95\% confidence intervals (Cls).

Results: Twenty-nine animal studies, including 1266 animals, were identified. None of the studies was judged to have a low risk of bias. The meta-analysis demonstrated that MSC therapy was related to a significantly lower mortality rate (OR $0.29,95 \% \mathrm{Cl} 0.22-0.38, P<0.001)$. Subgroup analyses performed based on the MSC injection dose $\left(<1.0 \times 10^{6}\right.$ cells, OR $=0.33,95 \% \mathrm{Cl} 0.20-0.56, P<0.001 ; 1.0 \times 10^{6}$ cells, OR $\left.=0.24,95 \% \mathrm{Cl} 0.16-0.35, P<0.001\right)$ and injection time $(<1 \mathrm{~h}, \mathrm{OR}=0.24,95 \% \mathrm{Cl} 0.13-0.45, P<0.001 ; 1 \mathrm{~h}, \mathrm{OR}=0.28,95 \% \mathrm{Cl} 0.17-0.46, P<0.001)$ demonstrated that treatment with MSCs significantly reduced the mortality rate of animals with sepsis.

Conclusion: This up-to-date meta-analysis showed a connection between MSC therapy and lower mortality in sepsis animal models, supporting the potential therapeutic effect of MSC treatment in future clinical trials. The results in this study contradict a previous meta-analysis with regards to the ideal dose of MSC therapy. Thus, further research is required to support these findings.
\end{abstract}

Keywords: Mesenchymal stem cell therapy, Sepsis, Meta-analysis, Preclinical studies

\footnotetext{
* Correspondence: suntongwen@163.com

${ }^{\dagger}$ Xue-Yi Sun and Xian-Fei Ding contributed equally to this work.

General ICU, Henan Key Laboratory of Critical Care Medicine, The First Affiliated Hospital of Zhengzhou University, Zhengzhou Key Laboratory of Sepsis, Zhengzhou 450052, China
}

C C The Author(s). 2020 Open Access This article is licensed under a Creative Commons Attribution 4.0 International License, which permits use, sharing, adaptation, distribution and reproduction in any medium or format, as long as you give appropriate credit to the original author(s) and the source, provide a link to the Creative Commons licence, and indicate if changes were made. The images or other third party material in this article are included in the article's Creative Commons licence, unless indicated otherwise in a credit line to the material. If material is not included in the article's Creative Commons licence and your intended use is not permitted by statutory regulation or exceeds the permitted use, you will need to obtain permission directly from the copyright holder. To view a copy of this licence, visit http://creativecommons.org/licenses/by/4.0/ The Creative Commons Public Domain Dedication waiver (http://creativecommons.org/publicdomain/zero/1.0/) applies to the data made available in this article, unless otherwise stated in a credit line to the data. 


\section{Background}

Sepsis is a life-threatening organ dysfunction caused by a host of uncontrolled responses to infection [1]. Sepsis is a common cause of patient hospital admission and death in the intensive care unit (ICU) [2], causing one third to one half of all deaths in hospital [3] and killing more than six million individuals worldwide each year [4]. Currently, there is no effective treatment for sepsis, and its management mainly focuses on controlling the source, as well as antibiotic application along with organ function support [5]. Due to the high mortality of sepsis, there is an unmet need for identifying considerable medical therapy for sepsis.

Mesenchymal stem cell (MSC) therapy has recently gained more attention due to the easy and fast isolation and expansion of MSCs in comparison to other stem cells, such as embryonic stem cells [6]. MSCs have multi-directional differentiation potential and can differentiate into many types of cells, such as adipocytes, chondroblasts, osteoblasts, and tissue macrophage-like cells, making MSCs one of the most necessary and promising sources of new clinical treatment $[7,8]$. Related studies have been widely performed in the context of many different diseases, such as graft versus host disease, progressive multiple sclerosis, diabetes, stroke, bronchopulmonary dysplasia, cardiomyopathy, and osteoarthritis [9]. Undoubtedly, because these cells have immunomodulatory, anti-inflammatory, antibacterial, and differentiation properties, MSCs are currently one of the most promising treatment options [9]. Despite the multiple studies conducted over the past decade, further research is still needed to confirm whether MSCs have definite beneficial effects on the management of sepsis.

Several animal studies that focus on sepsis have been reported [10-33], but these studies use different experimental designs and yield contradictory results. Thus, further preclinical studies are still required to evaluate the risks of new treatments and predict the safety or effectiveness of the therapy. In addition, such research can provide references and recommendations for unresolved issues in clinical stem cell therapy. Therefore, we conducted a systematic review of the literature and meta-analysis to assess the effectiveness of MSC treatment in animals with sepsis.

\section{Methods}

This meta-analysis was performed according to the Preferred Reporting Items for Systematic Reviews and Meta-Analyses (PRISMA) criteria [34]. The analysis of data available in published articles does not require ethical approval and patient consent. All supporting data is provided in this article and supplemented online.

\section{Data sources and search strategies}

The researchers conducted a systematic literature search using four databases, including MEDLINE, EMBASE, Cochrane Library, and Web of Science, to screen for targeted studies on the efficacy of MSCs in treating sepsis. The detailed search strategy is shown in Additional file 1: Table S1. The last search was updated on October 31, 2019. English was chosen as our search language. Later, all lists of references from the related articles (reviews, systematic reviews, meta-analyses, and included studies) were scanned by hand to retrieve additional studies that were not listed in the above databases. Two independent investigators blindly performed the literature search (XY Sun and XF Ding).

\section{Eligibility criteria}

The studies included in this meta-analysis fulfilled the following criteria: (1) the study evaluated the efficacy of MSC treatment in sepsis animal models (all species and sexes), (2) the study was written in English, (3) The study involved animal models of sepsis or endotoxemia, and (4) the study reported the evaluation index, including mortality. If more than one article contained overlapping data, the most informative or recent article was used.

The exclusion criteria were as follows: (1) the MSCs used in the study were differentiated, altered, or designed to overexpress or express specific genes; (2) the animal models suffered from sepsis but did not accept MSC therapy; (3) the animal models had other comorbidities; (4) the animals did not suffer from sepsis; (5) the study had insufficient data to obtain endpoint outcomes of interest; (6) the study did not have a control group; and (7) the study was duplicated.

\section{Study selection and data extraction}

Based on the search strategy to identify studies that met the above inclusion criteria, XY Sun and SH Liu retrieved the title and/or abstract of the studies from the database search, as well as from the supplementary resources. The main data disclosure was carried out separately by XJ Zhang and TW Sun. Any disagreements were resolved through discussions with $\mathrm{B}$ Han and XG Duan. The collected data was as follows: author and publishing year, animal characteristics (species, gender, sample size, and model), intervention characteristics (origin, dose, route, and timing of the MSC treatment), follow-up (time to observe results after MSC administration), and our primary measures related to secondary outcomes. If available, the odds ratio (OR) and its related 95\% confidence interval (CI) were extracted directly from the original article. Otherwise, the OR and 95\% CI were calculated from the individual patient data in the study. 


\section{Assessment of risk of bias (RoB)}

The RoB of the experimental animal studies was evaluated using the Systematic Review Centre for Laboratory Animal Experimentation (SYRCLE) RoB tool [35]. This tool is based on the Cochrane RoB tool and has been adjusted for aspects of bias that play a specific role in animal intervention studies. Widespread adoption and implementation of this tool will facilitate and improve the critical appraisal of evidence from animal studies. This may subsequently enhance the efficiency of translating animal research into clinical practice and increase awareness of the necessity for improving the methodological quality of animal studies. The resulting tool for animal studies contains 10 entries. These entries are related to six types of bias. Entries in this tool are as follows: selection bias (sequence generation, baseline characteristics, and allocation concealment), performance bias (random accommodation and blinding), detection bias (random outcome assessment and blinding), attrition bias (incomplete outcome data), reporting bias (selective outcome reporting), and other sources of bias. For each included study, the RoB was scored as high, low, or unclear.

\section{Primary outcomes}

The main study outcome of this meta-analysis was mortality.

\section{Statistical analysis}

The sepsis mortality rate was the OR taken as the effect size, and each effect size was expressed with a $95 \%$ CI. In addition, $\chi^{2}$ and $I^{2}$ tests were used to measure heterogeneity, where a $P>0.1$ and $I^{2}<50 \%$ was considered to be low heterogeneity $[36,37]$. If there was no heterogeneity, the inverse variance method of the fixed effects model was used for meta-analysis [38, 39]. If heterogeneity was present, subgroup analysis was performed to explore the potential sources of the heterogeneity and to consider whether meta-analysis could be conducted using a random effects model. Begg's funnel plot and Egger's linear regression were used to assessing potential publication bias [40]. All analyses were performed using Stata 14.0 statistical software (Stata Corp LP, College Station, Texas 77,845, USA). Differences with a $P<0.05$ (two-sided) were considered statistically significant.

\section{Results}

\section{Study selection}

According to the search strategy, a total of 1039 studies were identified and 704 studies remained after deleting duplicates. After preliminarily screening the titles and abstracts, 128 articles reporting the potential of MSCs for the treatment of sepsis were isolated for full-text review. Ultimately, 25 articles [10-33, 41] involving 1266 animals were included in this meta-analysis. The inclusion process and the reasons for the removal of certain studies are shown in Fig. 1.

\section{Study characteristics}

The basic characteristics of the included studies are shown in Table 1 . The articles were published between 2009 and 2019, with sample sizes ranging from 14 to 139. The sepsis animal models in most studies were induced by cecal ligation and puncture (CLP) or intraperitoneal injection of lipopolysaccharide (LPS). The animals used included rats and mice. Regarding the characteristics of the MSCs used for intervention, the MSCs were mainly derived from human or rat bone marrow, adipose-derived mesenchymal tissue, or human umbilical cord blood-derived mesenchymal tissue, with intervention doses ranging from $10^{5}$ to $10^{7}$ MSCs. Most of the MSCs were injected intravenously or intraperitoneally within a few hours of the induction of the sepsis animal models. In addition, four of the articles $[10,13,29,32]$ included multiple studies. Thus, the meta-analysis included a total of 29 animal studies with 1266 animals.

\section{Assessment of RoB}

Table 2 shows the RoB assessment results for the included studies. No study was considered to have low RoB. The included studies showed similarities between the baselines of the experimental and control groups, reducing the risk of selection bias in accordance with the animal characteristics. Despite the random allocation of experimental and control subjects, none of the studies clearly described the generation of random sequences. Therefore, the RoB was judged to be "unclear" in the sequence generation domain of all the included studies. However, no study properly described the method of concealed allocation, animals were randomly fed, researchers were blind to the interventions that each animal received, a randomized outcome evaluation was reported, and, in one study [21], the blindness of the evaluator was recorded. Using the provided signal questions, the risk of attrition bias and reporting bias in all of the included studies was low. The data in two of the studies $[12,26]$ was inadequate. Three of the studies $[10,13,15]$ may have had other problems that pose a high $\mathrm{RoB}$, including pollution, experimental design, and so on. In addition, we did not identify any additional sources of bias and bias tools for systematic risks that were not covered.

\section{Effect of MSC therapy on sepsis}

A total of 29 animal studies involving 1266 animals were used in this meta-analysis and reported animal mortality rates. Heterogeneity test results showed $I^{2}=14.5 \%$ and $P=0.248$, indicating that the heterogeneity between the studies was low; thus, a fixed effects model was used. As 


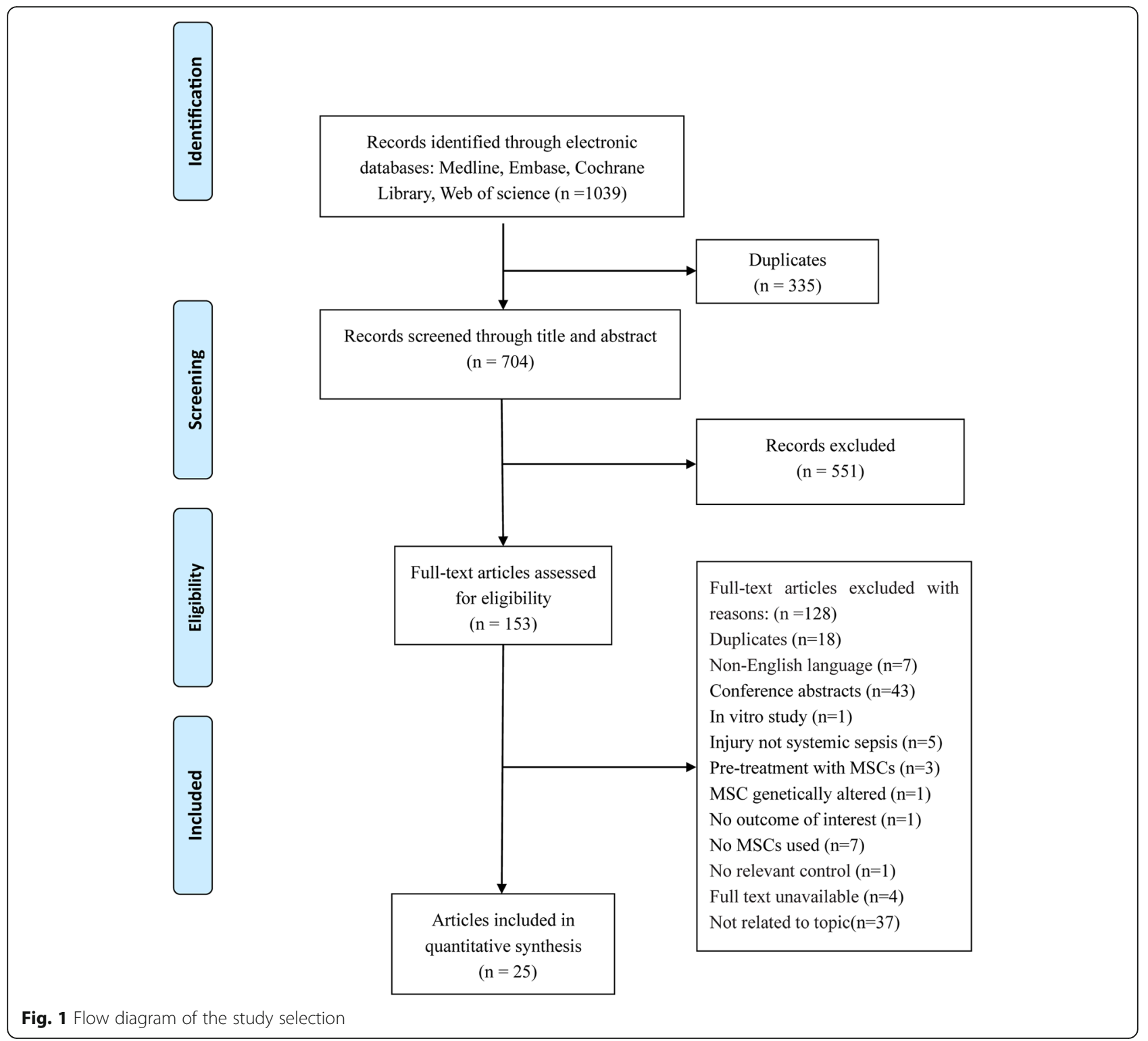

shown in Fig. 2, the pooled results demonstrated that the mortality of the animals after MSC treatment was significantly reduced (OR $0.29,95 \%$ CI $0.22-0.38, P<$ 0.001).

\section{Sensitivity analysis}

Sensitivity analysis was performed by eliminating any one of the 29 studies one by one, and assessing whether the combined effect value still fell within the total combined effect value of the $95 \% \mathrm{CI}$, indicating that the results of the meta-analysis were stable.

\section{Subgroup analysis}

Subgroup analysis was performed based on the animal species and model, as well as the MSC source, dose, injection time, and injection route. Both injection doses of $1.0 \times 10^{6}$ MSCs $(\mathrm{OR}=0.24,95 \%$ CI $0.16-0.35, P<$ $0.001)$ and less than $1.0 \times 10^{6}$ MSCs $(\mathrm{OR}=0.33,95 \% \mathrm{CI}$ $0.20-0.56, P<0.001)$, as well as the injection times of less than $1 \mathrm{~h}(\mathrm{OR}=0.24,95 \%$ CI $0.13-0.45, P<0.001)$ and $1 \mathrm{~h}(\mathrm{OR}=0.28,95 \% \mathrm{CI} 0.17-0.46, P<0.001)$ after sepsis induction in the animal models, significantly reduced the mortality rate (Additional files 2 and 3: Figs. S1 and S2). Intravenous injection of MSCs significantly reduced the mortality rate of the sepsis animal models $(\mathrm{OR}=0.28,95 \%$ CI $0.21-0.38, P<0.001)$ compared to intraperitoneal administration (OR $=0.37$, 95\% CI 0.20 $0.69, P<0.001$ ) (Additional file 4: Fig. S3). MSCs administered to mice were more effective $(\mathrm{OR}=0.24,95 \% \mathrm{CI}$ $0.17-0.34, P<0.001)$ than MSCs administered to rats 


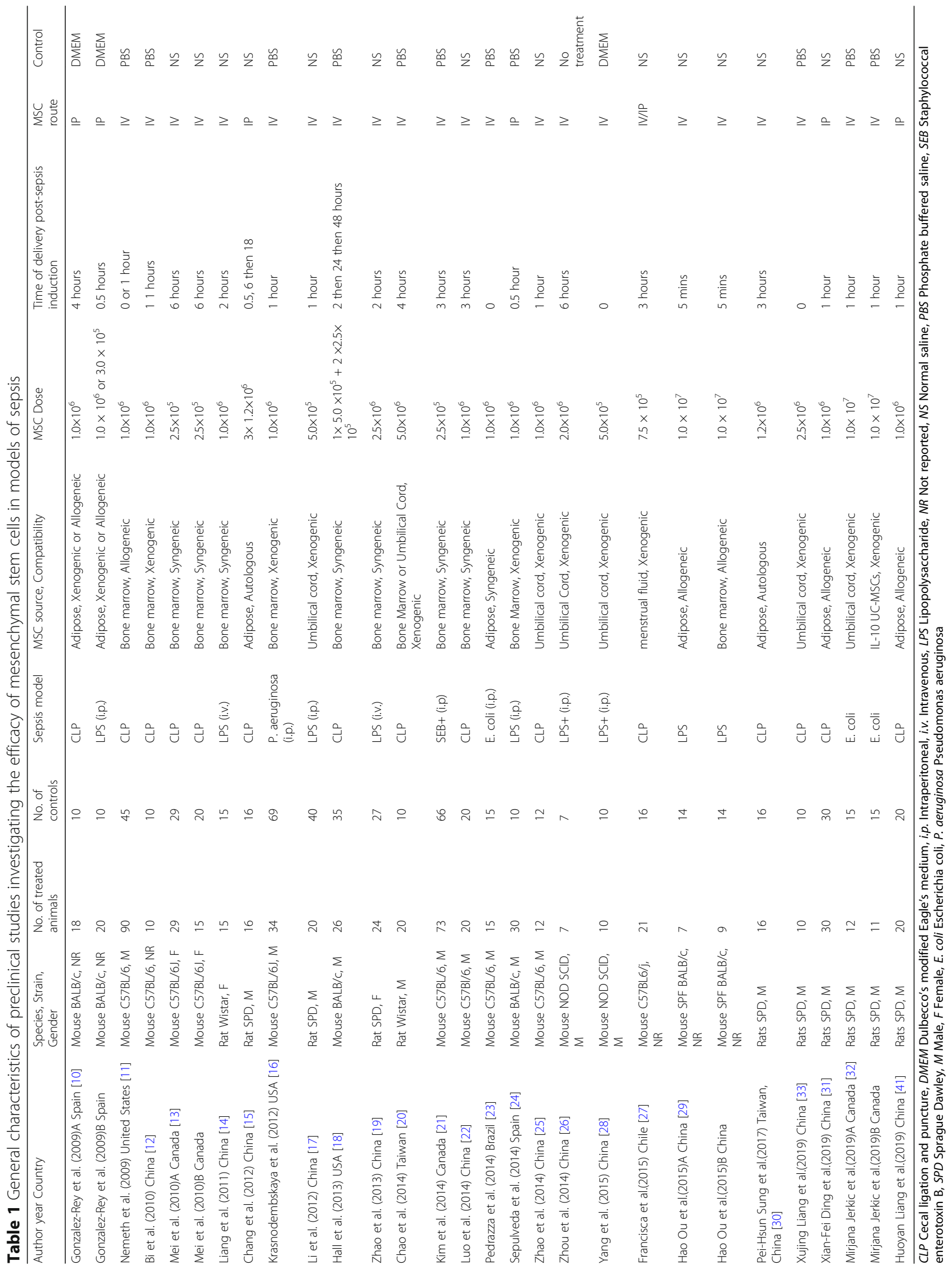


Table 2 SYRCLE Risk of Bias Assessment for included studies

\begin{tabular}{|c|c|c|c|c|c|c|c|c|c|c|}
\hline Author (Year) & $\begin{array}{l}\text { Random } \\
\text { sequence } \\
\text { generation? }\end{array}$ & $\begin{array}{l}\text { Groups } \\
\text { similar at } \\
\text { baseline? }\end{array}$ & $\begin{array}{l}\text { Allocation } \\
\text { concealed? }\end{array}$ & $\begin{array}{l}\text { Animals } \\
\text { randomly } \\
\text { housed? }\end{array}$ & $\begin{array}{l}\text { Blinding of } \\
\text { caregivers } \\
\text { and/or } \\
\text { examiners? }\end{array}$ & $\begin{array}{l}\text { Random } \\
\text { selection for } \\
\text { outcome } \\
\text { assessment? }\end{array}$ & $\begin{array}{l}\text { Blinding } \\
\text { of } \\
\text { outcome } \\
\text { assessor? }\end{array}$ & $\begin{array}{l}\text { Incomplete } \\
\text { outcome } \\
\text { data } \\
\text { addressed? }\end{array}$ & $\begin{array}{l}\text { Free from } \\
\text { selective } \\
\text { outcome } \\
\text { reporting? }\end{array}$ & $\begin{array}{l}\text { Free } \\
\text { from } \\
\text { other } \\
\text { bias? }\end{array}$ \\
\hline $\begin{array}{l}\text { Gonzalez-Rey } \\
\text { et al.(2009) [10] }\end{array}$ & U & U & U & U & U & U & U & L & L & $\mathrm{H}$ \\
\hline $\begin{array}{l}\text { Nemeth et al. } \\
\text { (2009) [11] }\end{array}$ & U & U & U & U & U & U & U & L & L & $\mathrm{L}$ \\
\hline $\begin{array}{l}\text { Bi et al. } \\
\text { (2010) [12] }\end{array}$ & U & U & U & U & U & U & U & $\mathrm{H}$ & $\mathrm{L}$ & $L$ \\
\hline $\begin{array}{l}\text { Mei et al. } \\
\text { (2010) [13] }\end{array}$ & U & U & U & U & U & U & U & L & L & $\mathrm{H}$ \\
\hline $\begin{array}{l}\text { Liang et al. } \\
\text { (2011) [14] }\end{array}$ & U & U & U & U & U & U & U & U & L & L \\
\hline $\begin{array}{l}\text { Chang et al. } \\
\text { (2012) [15] }\end{array}$ & U & U & U & U & U & U & U & U & L & $\mathrm{H}$ \\
\hline $\begin{array}{l}\text { Krasnodembskaya } \\
\text { et al.(2012) [16] }\end{array}$ & U & U & U & U & U & U & U & U & $\mathrm{L}$ & L \\
\hline $\begin{array}{l}\text { Li et al. } \\
\text { (2012) [17] }\end{array}$ & U & U & U & U & U & U & U & U & L & L \\
\hline $\begin{array}{l}\text { Hall et al. } \\
\text { (2013) [18] }\end{array}$ & U & U & U & U & U & U & U & U & L & L \\
\hline $\begin{array}{l}\text { Zhao et al. } \\
\text { (2013) [19] }\end{array}$ & U & U & U & U & U & U & U & U & $\mathrm{L}$ & L \\
\hline $\begin{array}{l}\text { Chao et al. } \\
\text { (2014) [20] }\end{array}$ & U & U & U & U & U & U & U & U & $\mathrm{L}$ & L \\
\hline $\begin{array}{l}\text { Kim et al. } \\
\text { (2014) [21] }\end{array}$ & U & U & U & U & U & U & $\mathrm{H}$ & U & $\mathrm{L}$ & L \\
\hline $\begin{array}{l}\text { Luo et al. } \\
\text { (2014) [22] }\end{array}$ & U & U & U & U & U & U & U & U & L & L \\
\hline $\begin{array}{l}\text { Pedrazza et al. } \\
\text { (2014) [23] }\end{array}$ & U & U & U & U & U & U & U & U & $\mathrm{L}$ & $\mathrm{L}$ \\
\hline $\begin{array}{l}\text { Sepulveda } \\
2014 \text { [24] }\end{array}$ & U & U & U & U & U & U & U & U & $\mathrm{L}$ & $\mathrm{L}$ \\
\hline $\begin{array}{l}\text { Zhao et al. } \\
\text { (2014) [25] }\end{array}$ & U & U & $U$ & U & U & U & U & U & $L$ & $L$ \\
\hline $\begin{array}{l}\text { Zhou et al. } \\
\text { (2014) [26] }\end{array}$ & U & $U$ & $U$ & $U$ & U & U & $U$ & $\mathrm{H}$ & $\mathrm{L}$ & $\mathrm{L}$ \\
\hline $\begin{array}{l}\text { Yang et al. } \\
\text { (2015) [28] }\end{array}$ & $U$ & $U$ & $U$ & $U$ & $U$ & U & $U$ & $U$ & $\mathrm{~L}$ & $\mathrm{~L}$ \\
\hline $\begin{array}{l}\text { Francisca et al. } \\
\text { (2015) [27] }\end{array}$ & $U$ & $U$ & $U$ & $U$ & $U$ & $U$ & $U$ & $\mathrm{~L}$ & $\mathrm{~L}$ & $\mathrm{~L}$ \\
\hline $\begin{array}{l}\text { Hao Ou et al. } \\
\text { (2015) [29] }\end{array}$ & $U$ & $U$ & $U$ & $U$ & U & $U$ & $U$ & $\mathrm{~L}$ & $\mathrm{~L}$ & $\mathrm{~L}$ \\
\hline $\begin{array}{l}\text { Pei-Hsun Sung et } \\
\text { al. (2017) [30] }\end{array}$ & $U$ & $U$ & $U$ & $U$ & $U$ & $U$ & $U$ & $\mathrm{~L}$ & $\mathrm{~L}$ & $\mathrm{~L}$ \\
\hline $\begin{array}{l}\text { Xujing Liang et al. } \\
\text { (2019) [33] }\end{array}$ & $U$ & $U$ & $U$ & $U$ & $U$ & $U$ & $U$ & $\mathrm{~L}$ & $\mathrm{~L}$ & $\mathrm{~L}$ \\
\hline $\begin{array}{l}\text { Xian-Fei Ding et } \\
\text { al. (2019) [31] }\end{array}$ & $U$ & $U$ & $U$ & $U$ & $U$ & $U$ & $U$ & $\mathrm{~L}$ & $\mathrm{~L}$ & $\mathrm{~L}$ \\
\hline $\begin{array}{l}\text { Mirjana Jerkic et } \\
\text { al. (2019) [32] }\end{array}$ & $U$ & $U$ & $U$ & $U$ & $U$ & $U$ & $U$ & $U$ & $U$ & $U$ \\
\hline $\begin{array}{l}\text { Huoyan Liang et } \\
\text { al. (2019) [41] }\end{array}$ & $U$ & $U$ & $U$ & $U$ & $U$ & $U$ & $U$ & $\mathrm{~L}$ & $\mathrm{~L}$ & $\mathrm{~L}$ \\
\hline
\end{tabular}




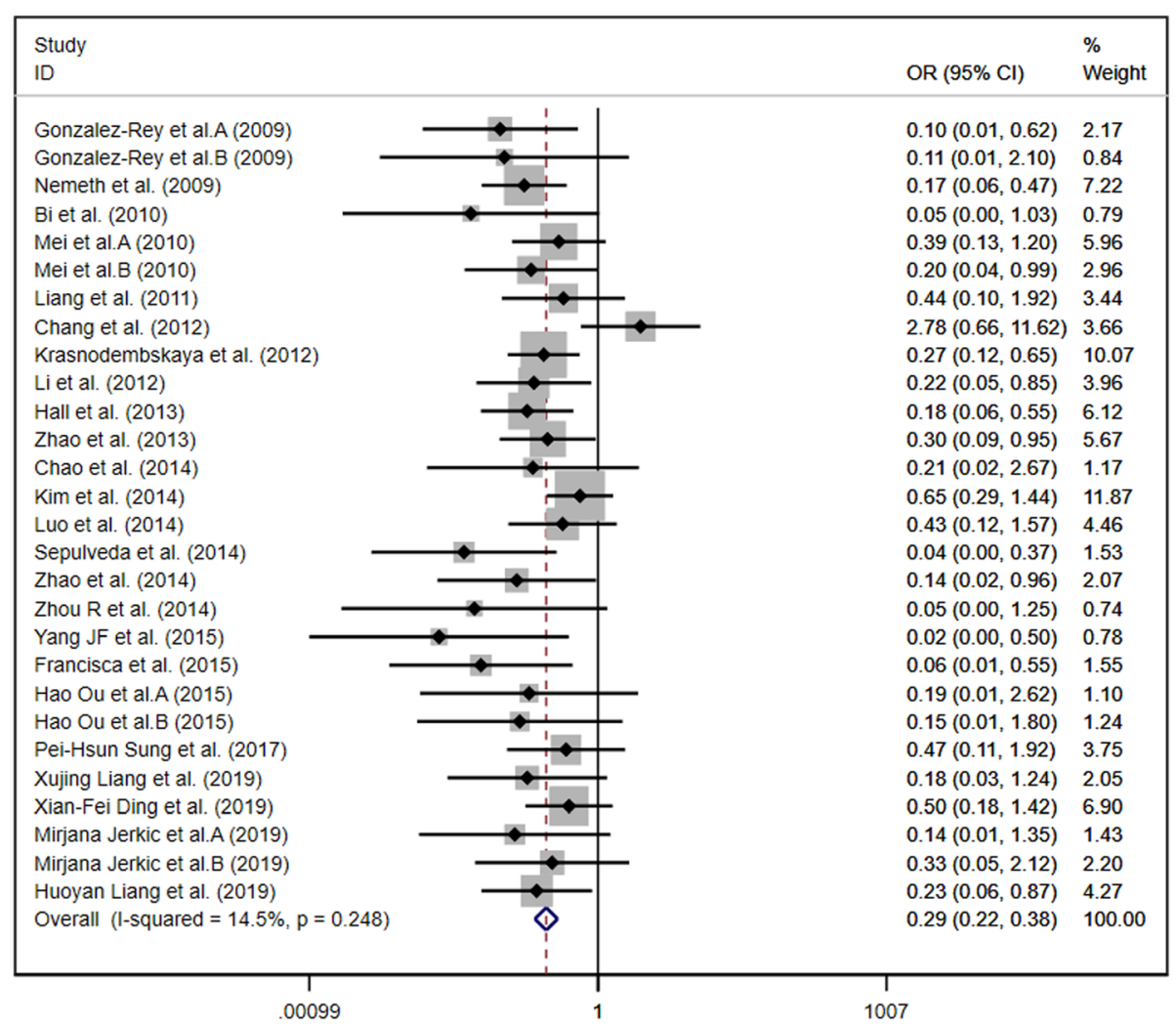

Favours mesenchymal stem cells Favours control

Fig. 2 Forest plot summarizing the effects of mesenchymal stem cell therapy on the mortality of preclinical models of sepsis and endotoxemia

$(\mathrm{OR}=0.39,95 \% \mathrm{CI} 0.25-0.60, P<0.001)$ (Additional file 5 : Fig. S4). However, there was no significant difference between the mortality rates of the CLP-induced sepsis animal model $(\mathrm{OR}=0.29,95 \% \mathrm{CI} 0.20-0.42, P<0.001)$ and the no-CLP sepsis animal model $(\mathrm{OR}=0.29,95 \% \mathrm{CI}$ $0.22-0.38, P<0.001$ ) (Additional file 6: Fig. S5). Furthermore, umbilical cord-derived MSCs significantly reduced the mortality rate of sepsis in the animal models $(\mathrm{OR}=0.14,95 \%$ CI $0.06-0.32, P<0.001)$. Only one study [27] showed that menstrual fluid-derived MSCs are efficacious for sepsis treatment $(\mathrm{OR}=0.06$, 95\% CI 0.01-0.55, $P<0.001)$; however, this finding should be interpreted cautiously (Additional file 7: Fig. S6). Additionally, MSCs administered to male animal models $(\mathrm{OR}=0.31,95 \%$ CI $0.23-0.43, \quad P<$ 0.001 ) were more beneficial than those administered to female animal models (OR $=0.33$, 95\% CI 0.17 0.63, $P<0.001$ ) (Additional file 8: Fig. S7).

\section{Publication bias}

Begg's funnel plot was used to test the potential bias of the literature. The results of the Begg's funnel plot suggested that publication bias was likely present. The Egger's test also suggested asymmetry in the funnel plot $(P=0.002)$.

\section{Discussion}

Systematic reviews play a vital role in assessing whether preclinical data can be applied to clinical practice. Combining such reviews with meta-analyses enables a more comprehensive and objective assessment of scientific results. Multiple preclinical studies of sepsis animal models revealed that MSCs could improve sepsis and decrease the mortality rate of sepsis. However, thus far, MSC therapy has not been used in the clinical treatment of patients with sepsis. A previous meta-analysis [42] collected and evaluated preclinical evidence regarding the use of MSCs in animal models of sepsis and demonstrated that MSC therapy could reduce the odds of death. The updated meta-analysis presented here includes another seven high-quality studies [27, 29-33, 41] that were mainly published in recent 3 years, and confirms the potential therapeutic efficacy of MSCs for reducing the mortality rate of sepsis in animal models, thus, providing possibilities for MSC therapy in preclinical studies of sepsis. To our knowledge, two small clinical phase 1 trials [43, 44] have been performed to evaluate the safety and feasibility of MSC therapy in sepsis and septic shock patients. These trials showed no serious clinical or physiological safety signals, implying that MSC treatment was tolerated and safe for administration in critical patients with septic shock. 
In our study, MSC therapy significantly improved the mortality rate of sepsis animal models, supporting the potential use of MSC therapy in preclinical studies of sepsis. Moreover, our study revealed that umbilical cord-derived MSCs significantly reduced the mortality rate of animals with sepsis; however, there is one study [27] that indicated that menstrual fluid-derived MSCs were also efficacious. However, given the lack of related reports, further research is required to confirm these findings. Numerous subgroup analyses were performed based on the MSC injection dose $\left(<1.0 \times 10^{6} \mathrm{MSCs}\right.$ or $\left.1.0 \times 10^{6} \mathrm{MSCs}\right)$ and injection time $(<$ $1 \mathrm{~h}$ or $1 \mathrm{~h})$ and demonstrated that MSCs significantly reduced the mortality rate of animals with sepsis. The effectiveness of intravenous injection of MSCs was greater than that of intraperitoneal administration. Furthermore, MSC administration in mice was more effective than MSC administration in rats. Additionally, the beneficial effects of MSCs in male animal models were greater than in female animal models. The sex difference might be an essential factor for MSC administration. Compared to the previously published meta-analysis [42], we obtained similar results with regards to the ideal source of MSCs, the optimal injection time, and the ideal route of MSC injection. However, concerning the MSC therapy dose, our analysis yielded a different conclusion that the ideal dose is no more than $1.0 \times 10^{6}$ MSCs or equal to $1.0 \times 10^{6} \mathrm{MSCs}$, contradicting the conclusions reported in the previously published meta-analysis [42], where more than or equal to $1.0 \times 10^{6}$ MSCs was indicated as the ideal dose. Thus, further research is required to explore the ideal dose of MSCs for sepsis treatment.

Previous studies show that the early stages of sepsis are characterized by an excessive inflammatory state due to the overproduction of pro-inflammatory mediators, which triggers end-organ dysfunction and damage [45]. MSCs may have the ability to increase anti-inflammatory cytokines and reduce pro-inflammatory cytokines [10, 20, 21, 23]. Liang et al. [41] proved that adipose-derived mesenchymal stem cells (ADMSCs) can reduce liver damage and inflammation through soluble tumor necrosis factor receptor 1 (sTNFR1), and more importantly, ADMSCs can significantly improve the survival rate of rats with CLP-induced sepsis. Two studies $[33,46]$ suggest that the expression levels of various proinflammatory cytokines, such as tumor necrosis factor (TNF) $-\alpha$ and interleukin (IL)- 6 , are elevated in CLP rats or LPS-treated Kupffer cells. Moreover, these studies found that MSCs have inhibitory effects on the sepsis-induced overexpression of TNF- $\alpha$ and IL- 6 and enhancing effects on IL-4 and IL-10 expression in rats with sepsis and LPStreated Kupffer cells. Contrastingly, a recent study published in 2019 [6] yielded opposite results that suggested that MSCs may not reduce the systemic inflammatory response, but can reduce organ damage. Therefore, further studies should be carried out to explore the potential mechanism of MSC therapy.
The advantages of the meta-analysis conducted here are apparent. Firstly, our study provides an up-to-date metaanalysis of the effectiveness of MSCs in sepsis animal models. Although a previously published meta-analysis [42] assessed the effectiveness of MSCs in sepsis animal models, the meta-analysis presented here includes seven recently published high-quality studies [27, 29-33, 41]. Out of all the included studies, only one study showed no positive effect of MSC therapy on sepsis animal models $(\mathrm{OR}=2.78,95 \% \mathrm{CI}$ $0.66-11.62, P<0.001)$. Secondly, we conducted a thorough and careful literature search that obeyed publishing protocols to ensure a strict reviewing procedure. Thirdly, numerous subgroup analyses based on the various animal models, source of MSCs, route of MSC administration, dose of MSCs, and timing of MSC administration were conducted to increase the accuracy of our findings. Finally, the main results of this investigation are generally useful for later preclinical and clinical trials for sepsis treatment.

However, this meta-analysis also has several limitations. The funnel plots and Egger's linear regression tests revealed that the study might contain publication bias. All included studies were limited to published studies; thus, unpublished data was omitted, possibly reducing the accuracy of our results. Although our best efforts were made to conduct a comprehensive search of the current literature, it is possible that some related studies were missed. In addition, due to the strict inclusion criteria, the meta-analysis was limited to relatively small data sets, and these studies were subject to external publication bias. Finally, it is hard to comment on the clinical safety of MSC treatment. While immunogenicity is unrelated to MSC therapy [43, 44], other significant risks still exist. Previous meta-analyses have shown no direct relationship between MSC administration and acute poisoning, systemic failure, malignancy, or death [47-49]. Regarding the safety and effectiveness of MSCs in the treatment of sepsis, phase 1 clinical trials have been conducted [43, 44], but MSCs have not yet been used for the clinical treatment of sepsis. To our knowledge, a recent large-animal study [50], using the animal models of pigs, demonstrated that MSCs were not capable of reducing the mortality induced by sepsis. Concerning its small sample size, more large-animal studies are needed. In spite of the current limitations, to some extent, our results represent the trends in this research area.

\section{Conclusion}

The present meta-analysis included 25 studies involving a total of 1266 animals and indicated that MSC therapy for sepsis is associated with lower mortality in preclinical studies. In this regard, large-animal studies and largescale animal studies are needed. Furthermore, largescale, randomized, prospective clinical trials are required to determine the effectiveness and efficiency of MSCs for the treatment of sepsis in patients, thereby, substantially improving present treatment protocols. 


\section{Supplementary information}

Supplementary information accompanies this paper at https://doi.org/10. 1186/s13287-020-01730-7.

Additional file 1: Table S1. The detailed search strategy.

Additional file 2: Fig. S1. Forest plot summarizing the relationship between mesenchymal stem cell dose and mortality in preclinical models of sepsis and endotoxemia.

Additional file 3: Fig. S2. Forest plot summarizing the relationship between mesenchymal cell therapy timing of administration and mortality in preclinical models of sepsis and endotoxemia.

Additional file 4: Fig. S3. Forest plot summarizing the relationship between mesenchymal stem cell administration route (intravenous versus intraperitoneal injection) and mortality in preclinical models of sepsis and endotoxemia.

Additional file 5: Fig. S4. Forest plot summarizing the relationship between mesenchymal stem cell-treated animal model species (rat versus mouse) and mortality in preclinical models of sepsis and endotoxemia.

Additional file 6: Fig. S5. Forest plot summarizing the relationship between preclinical models of sepsis and endotoxemia (i.e. cecal ligation and puncture versus live bacteria or bacterial product administration) and mortality following treatment with mesenchymal stem cells.

Additional file 7: Fig. S6. Forest plot summarizing the relationship between mesenchymal stem cell source and mortality in preclinical models of sepsis and endotoxemia.

Additional file 8: Fig. S7. Forest plot summarizing the relationship between animal sex and mortality in preclinical models of sepsis and endotoxemia.

\section{Abbreviations}

MSCs: Mesenchymal stem cells; SYRCLE: Systematic Review Centre for Laboratory Animal Experimentation

\section{Acknowledgements}

We greatly thank the Chinese Evidence Based Medicine Center, West China Hospital, Sichuan University for providing the Stata 14.0 statistical software.

\section{Authors' contributions}

All authors contributed extensively to the work presented in this article. TWS, XYS, and XFD conceived the study. XYS and SHL performed the literature search and analyzed the data. XJZ and TWS contributed key data interpretations. XYS and XFD contributed to the study protocol and wrote the article. $\mathrm{BH}$ and $\mathrm{XGD}$ resolved any differences through discussions. TWS revised the article. The corresponding author had full access to all of the data and the final responsibility to submit the article for publication. The authors read and approved the final manuscript.

\section{Funding}

This study was supported by the Scientific and Technological Innovation leaders in Central Plains (Grant No. 194200510017), the Provincial Ministry Co-construction Project from the Medical Scientific and Technological Research Program of Henan Province (Grant No. SBGJ2018020), and the Science and Technology people-benefit project of Zhengzhou

(2019KJHM0001)

\section{Availability of data and materials}

All supporting data are included in the article and its additional files.

\section{Ethics approval and consent to participate}

Not applicable.

\section{Consent for publication}

Not applicable.

\section{Competing interests}

The authors declare that they have no competing interests.
Received: 27 February 2020 Revised: 28 April 2020

Accepted: 13 May 2020 Published online: 03 June 2020

\section{References}

1. Singer M, Deutschman CS, Seymour CW, Shankar-Hari M, Annane D, Bauer M, Bellomo R, Bernard GR, Chiche JD, Coopersmith CM, Hotchkiss RS, Levy MM, Marshall JC, Martin GS, Opal SM, Rubenfeld GD, van der Poll T, Vincent $J$, Angus DC. The third international consensus definitions for sepsis and septic shock (Sepsis-3). Jama. 2016;315:801-10.

2. Kaukonen KM, Bailey M, Suzuki S, Pilcher D, Bellomo R. Mortality related to severe sepsis and septic shock among critically ill patients in Australia and New Zealand, 2000-2012. Jama. 2014;311:1308-16.

3. Liu V, Escobar GJ, Greene JD, Soule J, Whippy A, Angus DC, Iwashyna TJ. Hospital deaths in patients with sepsis from 2 independent cohorts. Jama. 2014;312:90-2.

4. Fleischmann C, Scherag A, Adhikari NKJ, Hartog CS, Tsaganos T, Schlattmann P, Angus DC, Reinhart K. Assessment of global incidence and mortality of hospital-treated sepsis. Current estimates and limitations. Am J Respir Crit Care Med. 2015;193:259-72.

5. Rello J, Valenzuela-Sanchez F, Ruiz-Rodriguez M, Moyano S. Sepsis: a review of advances in management. Adv Ther. 2017;34:2393-411.

6. Laroye C, Boufenzer A, Jolly L, Cunat L, Alauzet C, Merlin JL, Yguel C, Bensoussan D, Reppel L, Gibot S. Bone marrow vs Wharton's jelly mesenchymal stem cells in experimental sepsis: a comparative study. Stem Cell Res Ther. 2019;10:192.

7. Jiang $Y$, Jahagirdar BN, Reinhardt RL, Schwartz RE, Keene CD, Ortiz-Gonzalez XR, Reyes M, Lenvik T, Lund T, Blackstad M, Du J, Aldrich S, Lisberg A, Low WC, Largaespada DA, Verfaillie CM. Pluripotency of mesenchymal stem cells derived from adult marrow. Nature. 2002;418:41-9.

8. Pittenger MF, Mackay AM, Beck SC, Jaiswal RK, Douglas R, Mosca JD, Moorman MA, Simonetti DW, Craig S, Marshak DR. Multilineage potential of adult human mesenchymal stem cells. Science (New York, N.Y.). 1999;284: $143-7$.

9. Laroye C, Gibot S, Reppel L, Bensoussan D. Concise review: mesenchymal stromal/stem cells: a new treatment for sepsis and septic shock? Stem Cells. 2017;35:2331-9

10. Gonzalez-Rey E, Anderson P, González MA, Rico L, Büscher D, Delgado M. Human adult stem cells derived from adipose tissue protect against experimental colitis and sepsis. Gut. 2009:58:929-39.

11. Németh K, Leelahavanichkul A, Yuen PST, Mayer B, Parmelee A, Doi K, Robey PG, Leelahavanichkul K, Koller BH, Brown JM, Hu X, Jelinek I, Star RA, Mezey E. Bone marrow stromal cells attenuate sepsis via prostaglandin E (2)dependent reprogramming of host macrophages to increase their interleukin-10 production. Nat Med. 2009;15:42-9.

12. Bi L-K, Tang B, Zhu B, Xie C-L, Li S, Lin T-X, Huang J, Zhang W, Zhu J-Y. Systemic delivery of IL-10 by bone marrow derived stromal cells has therapeutic benefits in sepsis therapy* systemic delivery of IL-10 by bone marrow derived stromal cells has therapeutic benefits in sepsis therapy*. Progress Biochemistry Biophysics Progress Biochemistry Biophysics. 2010;37: $678-85$

13. Mei SHJ, Haitsma JJ, Dos Santos CC, Deng Y, Lai PFH, Slutsky AS, Liles WC, Stewart DJ. Mesenchymal stem cells reduce inflammation while enhancing bacterial clearance and improving survival in sepsis. Am J Respir Crit Care Med. 2010:182:1047-57.

14. Liang ZX, Sun JP, Ping W, Tian Q, Yang Z, Chen LA. Bone marrow-derived mesenchymal stem cells protect rats from endotoxin-induced acute lung injury. Chinese Med J. 2011;124:2715-22.

15. Chang $C-L$, Leu S, Sung H-C, Zhen $Y-Y$, Cho C-L, Chen A, Tsai T-H, Chung SY, Chai H-T, Sun C-K, Yen C-H, Yip H-K. Impact of apoptotic adipose-derived mesenchymal stem cells on attenuating organ damage and reducing mortality in rat sepsis syndrome induced by cecal puncture and ligation. $J$ Transl Med. 2012;10:244

16. Krasnodembskaya A, Samarani G, Song Y, Zhuo H, Su X, Lee J-W, Gupta N Petrini M, Matthay MA. Human mesenchymal stem cells reduce mortality and bacteremia in gram-negative sepsis in mice in part by enhancing the phagocytic activity of blood monocytes. Am J Phys Lung Cell Mol Phys. 2012;302:L1003-13.

17. Li J, Li D, Liu X, Tang S, Wei F. Human umbilical cord mesenchymal stem cells reduce systemic inflammation and attenuate LPS-induced acute lung injury in rats. J Inflamm. 2012;9:33. 
18. Hall SRR, Tsoyi K, Ith B, Padera RF Jr, Lederer JA, Wang Z, Liu X, Perrella MA. Mesenchymal stromal cells improve survival during sepsis in the absence of heme oxygenase-1: the importance of neutrophils. Stem Cells. 2013;31:397-407.

19. Zhao Y, Yang C, Wang H, Li H, Du J, Gu W, Jiang J. Therapeutic effects of bone marrow-derived mesenchymal stem cells on pulmonary impact injury complicated with endotoxemia in rats. Int Immunopharmacol. 2013;15:24653.

20. Chao Y-H, Wu H-P, Wu K-H, Tsai Y-G, Peng C-T, Lin K-C, Chao W-R, Lee M-S, Fu Y-C. An increase in CD3+CD4+CD25+ regulatory $T$ cells after administration of umbilical cord-derived mesenchymal stem cells during sepsis. PLoS One. 2014;9:e110338.

21. Kim H, Darwish I, Monroy M-F, Prockop DJ, Liles WC, Kain KC. Mesenchymal stromal (stem) cells suppress pro-inflammatory cytokine production but fail to improve survival in experimental staphylococcal toxic shock syndrome. BMC Immunol. 2014;15:1.

22. Luo CJ, Zhang FJ, Zhang L, Geng YQ, Li QG, Hong Q, Fu B, Zhu F, Cui SY, Feng Z, Sun XF, Chen XM. Mesenchymal stem cells ameliorate sepsisassociated acute kidney injury in mice. Shock (Augusta, Ga.). 2014;41:123-9.

23. Pedrazza L, Lunardelli A, Luft C, Cruz CU, de Mesquita FC, Bitencourt S, Nunes FB, de Oliveira JR. Mesenchymal stem cells decrease splenocytes apoptosis in a sepsis experimental model. Inflammation Research. 2014;63: 719-28

24. Sepulveda JC, Tome M, Fernandez ME, Delgado M, Campisi J, Bernad A, Gonzalez MA. Cell senescence abrogates the therapeutic potential of human mesenchymal stem cells in the lethal endotoxemia model. Stem Cells. 2014;32:1865-77.

25. Zhao X, Liu D, Gong W, Zhao G, Liu L, Yang L, Hou Y. The toll-like receptor 3 ligand, poly(l:C), improves immunosuppressive function and therapeutic effect of mesenchymal stem cells on sepsis via inhibiting MiR-143. Stem Cells. 2014;32:521-33.

26. Zhou R, Li Z, He C, Li R, Xia H, Li C, Xiao J, Chen ZY. Human umbilical cord mesenchymal stem cells and derived hepatocyte-like cells exhibit similar therapeutic effects on an acute liver failure mouse model. PLoS One. 2014;9: e104392.

27. Alcayaga-Miranda F, Cuenca J, Martin A, Contreras L, Figueroa FE, Khoury M. Combination therapy of menstrual derived mesenchymal stem cells and antibiotics ameliorates survival in sepsis. Stem Cell Res Ther. 2015;6:199.

28. Yang JF, Cao HC, Pan QL, Yu J, Li J, Li LJ. Mesenchymal stem cells from the human umbilical cord ameliorate fulminant hepatic failure and increase survival in mice. Hepatobiliary Pancreatic Dis Int. 2015;14:186-93.

29. Ou H, Zhao S, Peng Y, Xiao X, Wang Q, Liu H, Xiao X, Yang M. Comparison of bone marrow tissue- and adipose tissue-derived mesenchymal stem cells in the treatment of sepsis in a murine model of lipopolysaccharide-induced sepsis. Mol Med Rep. 2016;14:3862-70.

30. Sung PH, Chiang HJ, Wallace CG, Yang CC, Chen YT, Chen KH, Chen CH, Shao PL, Chen YL, Chua S, Chai HT, Chen YL, Huang TH, Yip HK, Lee MS. Exendin-4-assisted adipose derived mesenchymal stem cell therapy protects renal function against co-existing acute kidney ischemia-reperfusion injury and severe sepsis syndrome in rat. Am J Transl Res. 2017:9:3167-83.

31. Ding XF, Liang HY, Sun JY, Liu SH, Kan QC, Wang LX, Sun TW. Adiposederived mesenchymal stem cells ameliorate the inflammatory reaction in CLP-induced septic acute lung injury rats via sTNFR1; 2019.

32. Jerkic M, Masterson C, Ormesher L, Gagnon S, Goyal S, Rabani R, Otulakowski G, Zhang H, Kavanagh BP, Laffey JG. Overexpression of IL-10 enhances the efficacy of human umbilical-cord-derived mesenchymal stromal cells in E. coli pneumosepsis. J Clin Med. 2019;8(6):847.

33. Liang X, Li T, Zhou Q, Pi S, Li Y, Chen X, Weng Z, Li H, Zhao Y, Wang H, Chen Y. Mesenchymal stem cells attenuate sepsis-induced liver injury via inhibiting M1 polarization of Kupffer cells. Mol Cell Biochem. 2019;452:187-97.

34. D. Moher, A. Liberati, J. Tetzlaff, D.G. Altman, a.t.P. Group, Preferred Reporting Items for Systematic Reviews and Meta-Analyses: The PRISMA Statement, Ann Internal Med, 151 (2009) 264-269.

35. Hooijmans CR, Rovers MM, de Vries RBM, Leenaars M, Ritskes-Hoitinga M, Langendam MW. SYRCLE's risk of bias tool for animal studies. BMC Med Res Methodol. 2014;14:43.

36. Pereira TV, Patsopoulos NA, Salanti G, loannidis JP. Critical interpretation of Cochran's Q test depends on power and prior assumptions about heterogeneity. Res Synth Methods. 2010;1:149-61.

37. Hoaglin DC. Misunderstandings about $Q$ and 'Cochran's $Q$ test' in metaanalysis. Stat Med. 2016;35:485-95.
38. Balestra P. Fixed effect models and fixed coefficient models. In: Mátyás $L$, Sevestre $P$, editors. The econometrics of panel data: handbook of theory and applications. Dordrecht: Springer; 1992. p. 30-45.

39. Borenstein M, Hedges LV, Higgins JPT, Rothstein HR. A basic introduction to fixed-effect and random-effects models for meta-analysis. Res Synth Methods. 2010;1:97-111.

40. Lau J, loannidis JPA, Terrin N, Schmid CH, Olkin I. The case of the misleading funnel plot. BMJ. 2006;333:597-600.

41. Liang $H$, Ding $X, Y u$ Y, Zhang H, Wang L, Kan Q, Ma S, Guan F, Sun T. Adipose-derived mesenchymal stem cells ameliorate acute liver injury in rat model of CLP induced-sepsis via sTNFR1. Exp Cell Res. 2019;383:111465.

42. Lalu MM, Sullivan KJ, Mei SH, Moher D, Straus A, Fergusson DA, Stewart DJ. Evaluating mesenchymal stem cell therapy for sepsis with preclinical metaanalyses prior to initiating a first-in-human trial, 5; 2016.

43. He X, Ai S, Guo W, Yang Y, Wang Z, Jiang D, Xu X. Umbilical cord-derived mesenchymal stem (stromal) cells for treatment of severe sepsis: aphase 1 clinical trial. Translational Res. 2018;199:52-61.

44. Schlosser K, Wang JP, Dos Santos C, Walley KR, Marshall J, Fergusson DA, Winston BW, Granton J, Watpool I, Stewart DJ, Mclntyre LA, Mei SHJ. Effects of mesenchymal stem cell treatment on systemic cytokine levels in a phase 1 dose escalation safety trial of septic shock patients. Crit Care Med. 2019; 47:918-25.

45. Osuchowski MF, Welch K, Siddiqui J, Remick DG. Circulating cytokine/ inhibitor profiles reshape the understanding of the SIRS/CARS continuum in sepsis and predict mortality. J Immunol (Baltimore, Md. : 1950). 2006;177: 1967-74.

46. Mei S, Wang S, Jin S, Zhao X, Shao Z, Zhang R, Yu X, Tong Y, Chen S, Chen Z, Li Q. Human adipose tissue-derived stromal cells attenuate the multiple organ injuries induced by sepsis and mechanical ventilation in mice. Inflammation. 2019;42:485-95.

47. Ding X-F, Liang H-Y, Yuan B, Li L-F, Wang T, Kan Q-C, Wang L-X, Sun T-W. Efficacy of stem cell therapy for pulmonary arterial hypertension: a systematic review and meta-analysis of preclinical studies. Stem Cell Res Ther. 2019;10:55

48. Qiu Y, Li M-Y, Feng T, Feng R, Mao R, Chen B-L, He Y, Zeng Z-R, Zhang S-H, Chen $\mathrm{M}-\mathrm{H}$. Systematic review with meta-analysis: the efficacy and safety of stem cell therapy for Crohn's disease. Stem Cell Res Ther. 2017:8:136.

49. Yubo M, Yanyan L, Li L, Tao S, Bo L, Lin C. Clinical efficacy and safety of mesenchymal stem cell transplantation for osteoarthritis treatment: a metaanalysis. PLoS One. 2017;12:e0175449.

50. Horak J, Nalos L, Martinkova V, Tegl V, Vistejnova L, Kuncova J, Kohoutova M, Jarkovska D, Dolejsova M, Benes J, Stengl M, Matejovic M. Evaluation of mesenchymal stem cell therapy for sepsis: a randomized controlled porcine study. Front Immunol. 2020;11:126.

\section{Publisher's Note}

Springer Nature remains neutral with regard to jurisdictional claims in published maps and institutional affiliations.

\section{Ready to submit your research? Choose BMC and benefit from:}

- fast, convenient online submission

- thorough peer review by experienced researchers in your field

- rapid publication on acceptance

- support for research data, including large and complex data types

- gold Open Access which fosters wider collaboration and increased citations

- maximum visibility for your research: over $100 \mathrm{M}$ website views per year

At $\mathrm{BMC}$, research is always in progress.

Learn more biomedcentral.com/submission 